\title{
Analysis of the Effectiveness and Contribution of Regional Income on the Revenue and Expenditure Budget Situbondo City
}

\author{
Ika Wahyuni $^{1}$, Randika Fandiyanto ${ }^{2}$ \\ Universitas Abdurachman Saleh ${ }^{1,2}$ \\ \{ikawahyuni@unars.ac.id ${ }^{1\}}$
}

\begin{abstract}
The potential abundant resources in Situbondo Regency are very possible to be used as a source of Locally-generated revenue (PAD), the low management of potential sources will have a direct impact on PAD revenue so that innovation is needed both in management and innovation of transaction tools that support the acquisition of PAD itself. This study aims to determine the degree of Regional Autonomy of Situbondo Regency, determine the amount of contribution of each source of PAD to PAD, determine the effectiveness of revenue from PAD sources and know the average count (Mean) regarding the effectiveness of revenue from PAD sources. The object of this research is Situbondo Regency with PAD data for 10 years, namely 2010 to 2019. The variables of this study are (a) the amount of contribution of each PAD source, namely the ratio between the revenue of each source of PAD and the total PAD and (b) the effectiveness of the source. PAD with a target of receiving PAD sources. It is said to be effective if the realization of revenue from PAD sources is greater than the target of revenue. This study uses secondary data taken from the Regional Revenue and Financial Management Office of Situbondo Regency. The degree of Regional Autonomy of Situbondo Regency shows the contribution of PAD to total Regional Revenue shows an average of $9.42 \%$ or still below $30 \%$, but the achievement of PAD in Situbondo Regency continues to increase from 2010 to 2019. Contribution of each source of PAD to the Total PAD in an average proportion shows Regional Tax of $20.16 \%$, Regional Retribution of $11.38 \%$, Results of Regionally Owned Companies and Management of Separated Regional Assets of 3.83\% Others Legitimate PAD of $64.3 \%$. These results indicate that the majority of revenues come from Other Legitimate PAD. The effectiveness of revenue from PAD sources showed a figure of $100.28 \%$ or "very effective", but for several periods the realization of revenue from PAD showed fluctuations in effectiveness. 2010 (100.97\%), 2011 (101.33\%), 2012 (102.29\%), 2013 (100.94\%), 2014 $(101.15 \%)$ and $2018(101,43 \%)$ indicates "very effective" criteria, but for 2015 (99.05\%), 2016 (97.18\%), 2017 (98.23\%) and 2019 (99.51\%) revenue realization areas are below the target set or fall into the "effective" category.
\end{abstract}

Keywords: efficiency; Effectiveness; Degree of Autonomy, Regional Original Income 


\section{Introduction}

Autonomy allows local governments to have the authority to manage their regional finances, including in increasing fiscal independence. The occurrence of a prolonged crisis has had an impact on almost all aspects and the order of life of the Indonesian people. Even though it feels bitter because it has caused adversity for the nation and people of Indonesia, the positive wisdom which is a blessing in disguised is the emergence of basic ideas and thoughts that have led to total reform in all aspects of the life of the state and nation.

The impact of this total reform, in terms of politics and state administration, was a paradigm shift from a centralized government system towards a decentralized government system. This kind of government gives flexibility to regions in the form of broad and responsible regional autonomy to regulate and manage the interests of local communities according to their own initiatives based on community aspirations in accordance with the conditions and potential of the region.

The Law Number 22 Year 1999 concerning Regional Government by granting broad, real and accountable authority to the Regions in a proportionate manner, which is realized by regulating, sharing and utilizing national resources, as well as Central and Regional Financial Balance, in accordance with the principles of democracy, participation, society, equity and justice, as well as regional potential and diversity, which are carried out within the framework of the Unitary State of the Republic of Indonesia. By granting autonomy to the regions, the government system adopted by the regions is a decentralized system. Decentralization is the transfer of governmental authority by the Central Government to the Autonomous region. Hereinafter referred to as Daerah, is a legal community unit having regional boundaries, is a legal community unit having certain regional boundaries authorized to regulate and manage the interests of the local community according to their own initiative based on community aspirations. With this authority, regions have the opportunity to creatively develop their potentials, and make this potential a competitive force for other regions in society [1].

Situbondo district has abundant potential resources to become a source of PAD, however, the low management of potential sources has an impact on regional revenue, so that regional autonomy is still low in fiscal terms. 2016 PAD revenue exceeds the planned target, but the largest revenue comes from regional-owned hospitals. In 2017 PAD experienced an increase but there was a decrease in levy receipts due to retribution income which was recorded as debt, with a total of 11 billion which should have been received to be 8,9 billion. Whereas in 2018 PAD Situbondo experienced growth exceeding the target of around $12 \%$ and Realization of PAD in 2019, increased by 22 percent, this was not due to an increase in PAD sources but due to the innovative tapping box transaction tool made by DPPKAD. So that the formulation of the problem is how much PAD revenue from the total regional revenue and the percentage of each source, the effectiveness of the acquisition and the average revenue of PAD. The formulation of the problem is how much PAD revenue from total regional revenue and the percentage from each source, the effectiveness of the acquisition and the average revenue of PAD.

This study aims to determine the degree of Regional Autonomy in Situbondo Regency, determine the amount of contribution of each source of PAD to PAD, determine the effectiveness of revenue from PAD sources and know the average count (Mean) regarding the effectiveness of revenue from PAD sources. The object of this research is Situbondo Regency with PAD data for 10 years, namely 2010 to 2019. The variables of this study are (a) the amount of contribution from each source of PAD, namely the ratio between the revenue of each PAD source and the total PAD and (b) the effectiveness of the source. PAD with the 
target of receiving PAD sources. It is said to be effective if the realization of revenue from PAD sources is greater than the target of revenue. This study uses secondary data taken from the Regional Revenue and Financial Management Office of Situbondo Regency.

\section{Literature Review}

Halim Explains that the main characteristics of a region that can implement autonomy are (1) regional financial capacity, meaning that the region must have the authority to be able to explore financial sources in the region, manage and use their own finances to finance government activities, and dependence on funds from the central government to flow to a minimum so that local revenue becomes a source of financial the amount is not small [2].

Various studies related to Regional Original Income (PAD) from II in Indonesia have been conducted by researchers. The results of research by Devas et al. (1989) using time series data for the 1979 / 1980-1983 / 1984 fiscal year show that of the overall Dati II revenue in Indonesia, the source of regional original opinion (PAD) only contributed $\pm 10 \%$, while almost $80 \%$ came from from subsidies and contributions from the central government and the remainder is regional loans. Regional Original Opinion (PAD) itself consists of Regional Taxes (23\%), service fees (49\%), revenue from government agencies (9\%), regional company profits $(2 \%)$, and other revenues $(17 \%)$. The results of other studies show that during the $1986 / 1987$ to 1992/1993 fiscal years, most of the second regions in Indonesia had a percentage of local revenue to total regional expenditure of less than $15 \%$. Furthermore, it was stated that, in 1992/1993 the composition of the largest contributor to PAD Dati II was held by regional retribution, which was $55.07 \%$ of the total $\mathrm{PAD}$, followed by regional pakaj at $26.60 \%$, other revenues of $9.68 \%$, revenue from agencies of $5.70 \%$, and revenue of BUMD by $2.95 \%$ [3].

Berwulo, found that the development of local revenue in the city of Jayapura from the beginning of the study to the end of the study continued to experience positive growth and even the growth that occurred continued to increase every year. The effectiveness of regional revenue, especially local revenue, continues to show positive numbers every year, even always showing an effectiveness rate above $100 \%$ each year, while Jayapura City's independence in terms of revenue is still relatively small, even in the initial year of the study it was below 10 . $\%$ and the highest self-reliance rate is still at $18 \%$, this shows that even though the original regional income of Jayapura city continues to grow positively every year, this does not promise independence because regional revenue from the central government budget allocation is still very large.

According to Kuncoro states that the more private parties who invest their capital in an area, of course, will be able to provide benefits for the region concerned, because an increase in investment will increase the provision of job opportunities and in the end will increase local revenue [4]. The causes of low PAD based on the results of Kuncoro's (2004) research include (1) the lack of role of regional companies as a source of regional income, (2) the high degree of centralization in taxation, (3) although local taxes are quite diverse, only a few can be relied on as a source of income revenue, (4) political reasons many people worry that if regions have high financial resources it will encourage disintegration and separatism, and (5) weaknesses in providing subsidies from the Central Government to Regional Governments.

According to Sijabat, local governments that have a high proportion of PAD in their regional revenues are expected to be able to manage them optimally to finance regional development and provide public services to their communities [5]. Some of the factors that contributed to the low contribution of PAD to the total revenue of Dati II were: (1) many large 
sources of income were extracted from a region II but were outside the authority of the local government concerned to collect them, (2) BUMD in general had not yet become a source of revenue reliable, (3) lack of public awareness of paying taxes, levies and other levies (4) low level of life and the economy of the community, and (5) lack of ability of the local government concerned to explore existing sources of income.

Nasir found that the contribution of district / city PAD sources throughout Indonesia for the 2007-2013 fiscal year was dominated by revenues from taxes which were categorized as having a good contribution [6]. Furthermore, other legal PAD, retribution and BUMD. The growth of each PAD source also fluctuates in accordance with the conditions and potential of each region. In addition, competence, creativity and perceptions of government administrators have an influence on the effectiveness of receiving local user fees. In certain cases the local levy is used for a specific purpose, but in many cases it is no more than a refund of the costs that have been incurred by the local government to meet the demands of community members.

According to Santoso, although PAD must be able to finance the entire regional expenditure budget, the proportion of PAD to total regional revenue is an indication of the degree of independence / capability of a region, often referred to as fiscal independence [7]. In line with the above statement, Kuncoro states that the indicator of fiscal decentralization is the ratio between Regional Original Income (PAD) and total regional revenue [3]. Apart from that, Harits (1995) explains that an important criterion of regional autonomy is that there is a balance between Central or Dati I Subsidies and Regional Original Income (PAD), even if PAD should be much greater than the subsidies received.

Research conducted by Yaneka \& Wayan shows that the efficiency level of regional tax and retribution revenue from Klungkung Regency in 2005-2011 is classified as efficient, which is an average of 70.97 percent [8]. The effectiveness level of local taxes and levies from Klungkung Regency in 2005-2011 was classified as very effective, namely an average of 112.36 percent. Researchers have compiled a development strategy related to this research, thus, to develop a regional economic degree determined from the development model and utilization of existing PAD potential, for this reason the application of technology that supports the acquisition of PAD such as innovation in tapping box transaction tools and potential utilization in various sectors is necessary to applied.

\section{Research Method}

The object of this research is Situbondo Regency with PAD data for 10 years, namely 2010 to 2019. The variables of this study are (a) the amount of contribution from each source of PAD, namely the ratio between the revenue of each PAD source and the total PAD and (b) the effectiveness of the source. PAD with the target of receiving PAD sources. It is said to be effective if the realization of revenue from PAD sources is greater than the target of revenue. This study uses secondary data taken from the Department of Revenue and Financial and Asset Management of Situbondo Regency. To determine the degree of Regional Autonomy of Situbondo Regency, it is used formula as follows:

a) To determine the degree of Regional Autonomy in Situbondo Regency, the following formula is used :

$\mathrm{D}=\frac{\text { Locally }- \text { generated revenue }}{\text { Total Regional Revenue }} \times 100 \%$ 
b) To determine the amount of contribution of each PAD source to PAD, the following formula is usedRegional Revenue;

$$
\mathrm{S}=\frac{\text { Receipt of PAD Resources }}{\text { Total PAD }} \times 100 \%
$$

c) To determine the effectiveness of revenue from PAD sources, the following formula is used ;

$$
\mathrm{X}=\frac{\text { Realization of Revenue from PAD Resources }}{\text { Revenue Target of PAD Resources }} \times 100 \%
$$

d) To determine the average count (Mean) regarding the effectiveness of revenue from PAD sources, the following formula is used;

$$
\mathrm{X}=\frac{\sum_{t=1}^{n} X i}{\mathrm{n}}
$$

dimana :

$\sum_{t=1}^{n} X i=$ the amount of effectiveness of receiving PAD sources during the year of observation

$\mathrm{n}=$ length of observation year

\section{Research Result}

\subsection{General Description of Local Original Revenue in Situbondo Regency}

The Government of Situbondo Regency strives to increase regional income, especially Regional Original Income (PAD) which is an indicator of the strength and independence of the Situbondo Regency Government. Original regional income is a component that allows the revenue to be developed and optimized, but it is also sought and considered so as not to add to the burden on the people of Situbondo Regency. The regional income of Situbondo Regency consists of:

\section{a) Locally-Generated Revenue (PAD)}

Original regional revenue is revenue obtained by a region from sources within its own territory which is collected based on regional regulations in accordance with the prevailing laws and regulations in Situbondo Regency, the source of PAD consists of three, namely: (1) Local tax, (2) Regional Retribution, (3) Separated BUMD Results and Regional Wealth and (4) Other Legal PAD.

\section{b) Balancing Funds}

Balancing funds through Government Regulation Number 55 of 2005 concerning Balancing Funds, it is explained that the Profit Sharing Fund (DBH) tax is the regional share derived from land and building taxes, fees for the acquisition of rights on land and buildings, 
income tax Article 25 and 29 individual taxpayers. domestic and income tax article 21, with the acceptance of the transfer of PBB and BPHTB taxes, since 2014 the two taxes have become PAD. The Balancing Fund consists of three sources, namely: (1) Tax / Non-Tax Profit Sharing, (2) General Allocation Fund and (3) Special Allocation Fund.

\section{c) Other Legitimate Income}

Other legal income, which consists of tax revenue sharing from the province, provincial financial assistance and other legal regional income.

\subsection{Degree of Regional Autonomy of Situbondo Regency}

One aspect that can determine the success of regional autonomy is the independence of local governments. Thus the implications of developing regional autonomy are not merely the addition of the functions assigned, but also how much of the delegated authority gives the ability to take initiatives in regional financial management including fiscal decentralization so that regions can reduce the degree of dependence on the center and can finance development activities. the area. The following is the data on the level or degree of regional autonomy of Situbondo Regency during the period 2011 to 2015 which is illustrated in table 5.1 below:

Tabel 1. Development of PAD of Situbondo Regency Year 2010 s.d 2019

\begin{tabular}{cllc}
\hline Years & \multicolumn{1}{c}{ Total Pad } & \multicolumn{1}{c}{ Total Revenue Of Region } & Pad Contribution \\
\hline 2010 & Rp. 46.615.898.585,26 & Rp. 680.912.828.347 & $6,85 \%$ \\
2011 & Rp. 61.689.526.247,44 & Rp. 851.142.771.731,44 & $7,25 \%$ \\
2012 & Rp. 67.050.480.515,22 & Rp. 985.535.428.645,22 & $6,80 \%$ \\
2013 & Rp. $78.043 .407 .931,91$ & Rp. $1.109 .471 .305 .726,91$ & $7,03 \%$ \\
2014 & Rp. $129.640 .577 .933,62$ & Rp. $1.359 .193 .748 .692,37$ & $9,54 \%$ \\
2015 & Rp. 48.289.946.658,47 & Rp. $1.520 .141 .963 .246,47$ & $9,76 \%$ \\
2016 & Rp. 73.836.184.925,12 & Rp. $1.580 .583 .084 .970,12$ & $11,00 \%$ \\
2017 & Rp. 26.535.409.803,24 & Rp. $1.618 .468 .100 .431,24$ & $14,00 \%$ \\
2018 & Rp. 87.287.219.449,41 & Rp. $1.755 .587 .299 .205,04$ & $10,67 \%$ \\
2019 & Rp. $204.727 .875 .621,05$ & Rp. 1.819.658.453.341,45 & $11,25 \%$ \\
\hline
\end{tabular}
Source: Data from BPPKAD of Situbondo City 2010-2019

The source of PAD in Situbondo regency has experienced significant growth every year. To measure the degree of regional autonomy in Situbondo Regency, it is done by comparing how much PAD contributes to total regional revenue. In 2011, the contribution of PAD of Situbondo Regency to total regional income was 7,247\%. In 2012 the contribution of PAD decreased, with a contribution rate of $6.80 \%$. In 2013, the contribution rate of PAD increased to 7,034 , this was resulted from the implementation of strategic steps taken to optimize regional revenue sources compared to the previous year. The increase was quite significant, to be precise in 2014 where the PAD contribution reached $9.53 \%$. and in 2015 it increased with a contribution rate of $9.75 \%$ and only increased by $0.22 \%$ from the previous year. 2016 shows a contribution of $11.00 \%$, in 2017 the contribution of PAD to total regional revenue is $14.00 \%$, this figure is the largest in the last ten years. Whereas for 2018 it shows the number $10.67 \%$ and in 2019 it is $11.25 \%$. Overall shows that the contribution of PAD to total regional revenue is quite small or below $30 \%$, but the achievement of PAD in Situbondo Regency has continued to increase from 2010 to 2019 , this achievement shows that the fiscal capacity of Situbondo Regency continues to increase well. The various policies that have been established 
by the Situbondo Regency Government have been able to boost economic growth for ten years and have an impact on the growth of PAD.

\subsection{Contribution of Each Source of PAD to Total PAD}

To find out the amount of contribution of each source of PAD to PAD, a formula is used by comparing each source of PAD with the total PAD obtained in the period 2010 to 2019. The results of calculating PAD contributions can be described in table 5.2 below:

Tabel 2. Contribution of each source of PAD to Total PAD of Situbondo City Years 2010 s.d 2019

\begin{tabular}{|c|c|c|c|c|c|c|c|c|c|c|c|c|}
\hline \multirow{2}{*}{ NO } & \multirow{2}{*}{ Source of Pad } & \multicolumn{10}{|c|}{ Percentage } & \multirow{2}{*}{ Avg } \\
\hline & & 2010 & 2011 & 2012 & 2013 & 2014 & 2015 & 2016 & 2017 & 2018 & 2019 & \\
\hline 1 & Local tax & 19,84 & 17,94 & 21,07 & 22,02 & 18,73 & 17,84 & 17,30 & 17,19 & 23,31 & 26,07 & 20,16 \\
\hline 2 & $\begin{array}{l}\text { Regional } \\
\text { Retribution }\end{array}$ & 17,64 & 14,81 & 17,58 & 20,52 & 11,71 & 14,31 & 7,87 & 4,25 & 5,64 & 5,69 & 11,38 \\
\hline 3 & $\begin{array}{l}\text { Proceeds from } \\
\text { Regional } \\
\text { Owned } \\
\text { Companies and } \\
\text { Separated } \\
\text { Regional Assets } \\
\text { Management }\end{array}$ & 7,56 & 8,13 & 6,32 & 5,50 & 3,16 & 2,85 & 2,48 & 1,79 & 2,23 & 1,98 & 3,83 \\
\hline 4 & $\begin{array}{l}\text { Other Legal } \\
\text { PAD }\end{array}$ & 54,97 & 59,12 & 55,03 & 51,96 & 66,40 & 64,99 & 72,34 & 76,76 & 68,82 & 66,26 & 64,63 \\
\hline
\end{tabular}

Source: Data from BPPKAD of Situbondo City 2010-2019

Based on the data above, it can be illustrated that the realization of PAD is obtained from local tax revenue, regional levies, the results of separated regional wealth management and other legal income. On average, the composition of PAD revenues consists of Regional Taxes of $20.16 \%$, Regional Retribution of $11.38 \%$, Results of Regionally Owned Companies and Management of Separated Regional Assets of 3.83\% Others Legitimate PAD of $64.3 \%$. From 2010 to 2019, the contribution of this type of income to the proportion of PAD in Situbondo Regency was still dominated by other legitimate revenues, and this is further illustrated in the graph of each source of PAD to the amount of PAD as Figure 1.

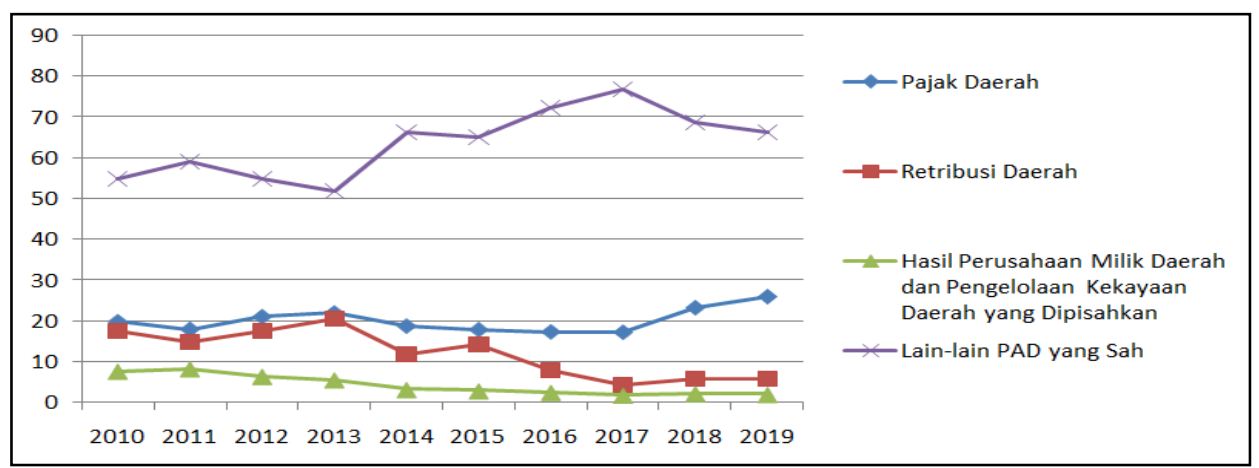

Fig. 1. Chart of Contribution of each source of PAD to Total PAD of Situbondo City Years 2010 s.d 2019

Source: Data Processed in 2020 
The results of regional companies and separated regional wealth management show the smallest contribution to total PAD, so the role of efforts to optimize the management of this source needs to be developed, such as banongan companies which continue to experience a decline in revenue until 2019, besides that the Pasir Putih Regional Company has not shown good income performance despite having received several capital investments has not yet shown a good financial performance. In addition, the Supreme Audit Agency (BPK) -RI also found allegations of leaks in retribution receipts from Perusda Pasir Putih. In addition, Perusda Banongan also experienced the same thing, up to three years running under the leadership of the new board of directors, Perusda Banongan has not made any concrete contributions because it is still entangled in tax debt. The second lowest contribution is regional retribution, in terms of the total portion of PAD is still decreasing, this is due to many factors both in terms of regulations, OPD collectors and objects collected. In terms of regional taxes, it is the second largest and continues to experience a growth trend, while the largest contribution to total PAD is from other legal PAD.

\subsection{The Effectiveness of Revenue from PAD Sources}

Effectiveness is basically related to the achievement of policy goals or targets, to determine the effectiveness of revenue from PAD sources, a comparative analysis is used between the planned PAD budget (target) and the Realization of PAD in Situbondo Regency. For effectiveness criteria based on Depdagri, Kepmendagri No. 690.900.327 Year 2006. can be seen in table 5.3 below:

Tabel 3. Effectiveness Criteria

\begin{tabular}{cc}
\hline Effectiveness & Criteria \\
\hline Lebih dari $100 \%$ & Very effective \\
$90 \%-100 \%$ & Effective \\
$80 \%-90 \%$ & Effective enough \\
$60 \%-80 \%$ & Less effective \\
Kurang dari $60 \%$ & Ineffective \\
\hline \multicolumn{2}{c}{ Depdagri, Kepmendagri No. 690.900.327 Year 2006}
\end{tabular}

The results of the analysis to compare the target and realization are carried out in detail every year to measure how effective the PAD revenue is in Situbondo Regency. Based on data for the period 2010 to 2019, Regional Revenue Revenue from Situbondo Regency shows a growth trend every year. This shows a very good local revenue performance. Effectiveness on average shows a figure of $100.28 \%$ or "very effective", but for several periods the realization of revenue PAD shows fluctuations in effectiveness. 2010 (100.97\%), $2011(101.33 \%), 2012$ (102.29\%), 2013 (100.94\%), 2014 (101.15\%) and 2018 (101, 43\%) indicates "very effective" criteria, but for 2015 (99.05\%), 2016 (97.18\%), 2017 (98.23\%) and 2019 (99.51\%) revenue realization areas are below the target set or fall into the "effective" category. Furthermore, it can be described in the following: 


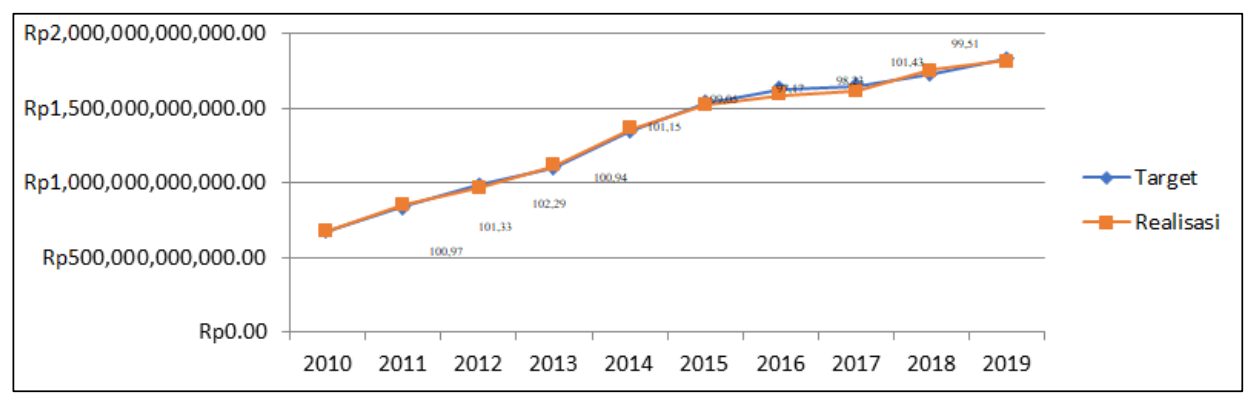

Fig. 2. Graph of Situbondo Regency Revenue Effectiveness from 2010 to 2019

Source: Data Processed in 2020

\subsection{Average Effectiveness of PAD Resources in 2010 to 2019}

The results of the discussion for the target and realization of Situbondo Regional Original Revenue were different in the range above and below $100 \%$, based on the effectiveness table it can be concluded that during the ten fiscal years from 2010 to 2019 the overall effectiveness of PAD sources for five years reached $105.22 \%$ which is very effective. The effectiveness of PAD sources from Regional Tax Results reaches 116.08 which means very effective, the effectiveness of PAD sources from the results of regional levies reaches $92 \%$ which means effective, the effectiveness of PAD sources from the results of Regionally Owned Companies and the Management of Separated Regional Assets reaches 100.58\%, The effectiveness of PAD sources from other legitimate PAD reaches 112.24 which means very effective. The results of the analysis of the effectiveness of each source of PAD can be seen in table 4 below:

Table 4. Effectiveness of PAD Sources

\begin{tabular}{|c|c|c|c|c|c|c|c|c|c|c|c|c|}
\hline \multirow[b]{2}{*}{ No } & \multirow{2}{*}{ Source Of Pad } & \multicolumn{10}{|c|}{ Percentage } & \multirow[b]{2}{*}{ Avg } \\
\hline & & 2010 & 2011 & 2012 & 2013 & 2014 & 2015 & 2016 & 2017 & 2018 & 2019 & \\
\hline 1 & Local tax & 112,05 & 119,27 & 121,52 & 120,31 & 122,08 & 99,53 & 112,55 & 116,81 & 113,93 & 122,73 & 116,08 \\
\hline 2 & $\begin{array}{l}\text { Regional } \\
\text { Retribution }\end{array}$ & 106,66 & 111,68 & 84,12 & 91,96 & 57,35 & 81,66 & 101,86 & 105,19 & 85,24 & 94,24 & 92,00 \\
\hline 3 & $\begin{array}{l}\text { Proceeds from } \\
\text { Regional Owned } \\
\text { Companies and } \\
\text { Separated Regional } \\
\text { Assets } \\
\text { Management }\end{array}$ & 138,04 & 99,46 & 83,31 & 102,07 & 100,00 & 102,22 & 100,00 & 82,14 & 98,04 & 100,52 & 100,58 \\
\hline 4 & Other Legal PAD & 104,50 & 119,41 & 123,54 & 108,75 & $\begin{array}{r}132,14 \\
\mathbf{A}\end{array}$ & $\begin{array}{l}110,00 \\
\text { ge }\end{array}$ & 108,95 & 105,59 & 104,53 & 105,01 & $\begin{array}{l}112,24 \\
\mathbf{1 0 5 , 2 2} \\
\end{array}$ \\
\hline
\end{tabular}

Source: Data of BPPKAD Situbondo City Year 2010-2019

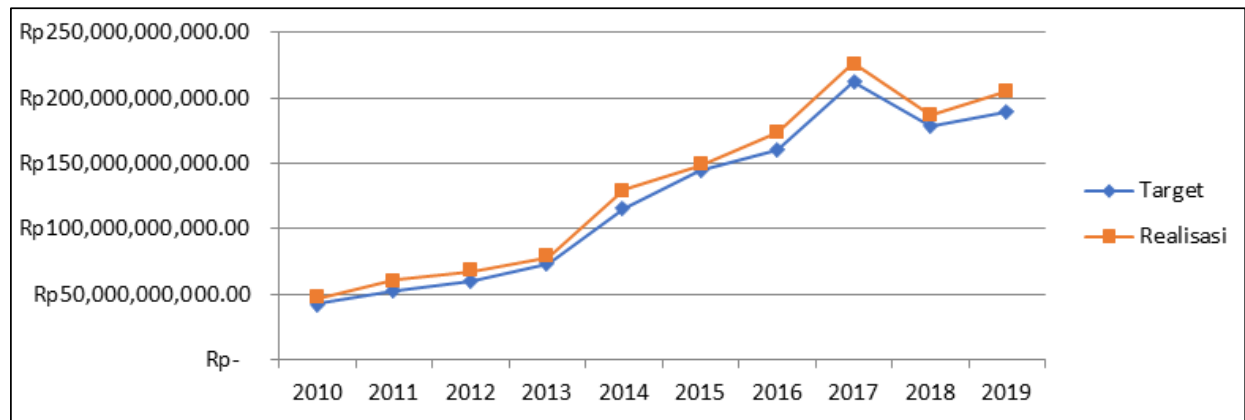

Fig. 3. Graph of the Total Effectiveness of PAD Situbondo in 2010-2019 Source: Data Processed in 2020 
The picture above shows that the overall growth trend of Situbondo Regency's total PAD from 2010 to 2017 has experienced significant growth, this is because it is driven by high revenues from regional retribution and PAD other legitimate PAD. In 2018, the total PAD of Situbondo Regency experienced a significant decrease of around Rp. 39,248,190,353.83, the decrease was due to the decrease in other PAD sources of legitimate PAD which resulted in a significant decrease in the PAD of Situbondo Regency. The following is a description of the effectiveness of PAD Sources from 2011 to 2019 from local tax sources, regional levies, regional-owned company results and management of separated regional assets and other legal PAD:

\subsection{PAD which Comes from Local Taxes}

Based on the Situbondo Regional Tax PAD Effectiveness Chart for 2010-2019, the development of PAD from regional taxes continues to develop, with an average effectiveness level of $116.08 \%$, and being the highest among several other PAD sources. Taxes are one of the pillars of the amount of regional income that will not experience a decline, due to the increasing number of tax subjects collected by the government. The analysis shows significant growth every year 2011 Rp. 11,064,631,607.03, which is an increase of around $19.6 \%$ from 2020 with total revenue of Rp. 9,246,964,308.00. In 2012, it was obtained around Rp. $14,128,755,468.60$ or an increase of $27.6 \%$. In 2013 , local tax revenues increased by around $21.6 \%$, namely Rp. $17,188,209,719.65$.

In 2014 the increase in income to Rp. $24,287,378,394.47$ or an increase of about $41.3 \%$. The growth in 2014 is the biggest in the last 10 years, this is dominated by the high acquisition of street lighting invites of around Rp. 10,926,953,628.00 and tax on acquisition of land and building rights 2,431,424,161.50. In 2015 the total regional revenue was Rp. $26,451,180,607.73$ or an increase of $8.9 \%$ of total revenue in the previous year, however, there are several problems with the low increase in tax revenue in 2015 including the realization of tax revenue sharing and central non-tax revenue sharing that are not in accordance with the revenue target in the APBD and there is income Rural and urban PBB taxes that have not reached the target are due to the fact that there are data objects that do not match conditions in the field. 2016 Rp. 30,080,834,208.29 namely $13.72 \%$. The increase in tax revenues in Kabuoaten Situbondo occurred again in 2017 where the total revenue was Rp. $38,951,117,757.34$ or an increase of $29.48 \%$. Besides, the total revenue in 2018 has increased again by $12 \%$, namely Rp. $43,654,005,946.48$ and the highest income in the last ten year period, namely in 2019 with total revenue of Rp. 53,364,172,516.00 or an increase of $22.2 \%$ from 2018.

Various efforts have been made by the government, including Strengthening Local Taxing Power through expanding tax objects, adding types of tax collections, increasing maximum rates and discretionary rate setting. In addition, the government has also made efforts to utilize technology in tax transactions as well as cooperation with financial service authorities, Intensifying and extending sources of regional income, coordinating synergistically, improving BUMD performance, improving tax service systems, encouraging law enforcement, adjusting legal bases, increasing coordination and communication with the central government as well as improving regional asset and financial management.

Types of taxes that have been received by PAD of Situbondo Regency in the last ten years include hotel tax, restaurant tax, entertainment tax, advertisement tax, street lighting tax, nonmetal mineral and rock tax, rural and urban land and building tax and land rights and fees. 
Building. The following is a chart of the effectiveness of Situbondo Regency PAD revenue which came from local taxes during the period 2010 to 2019.

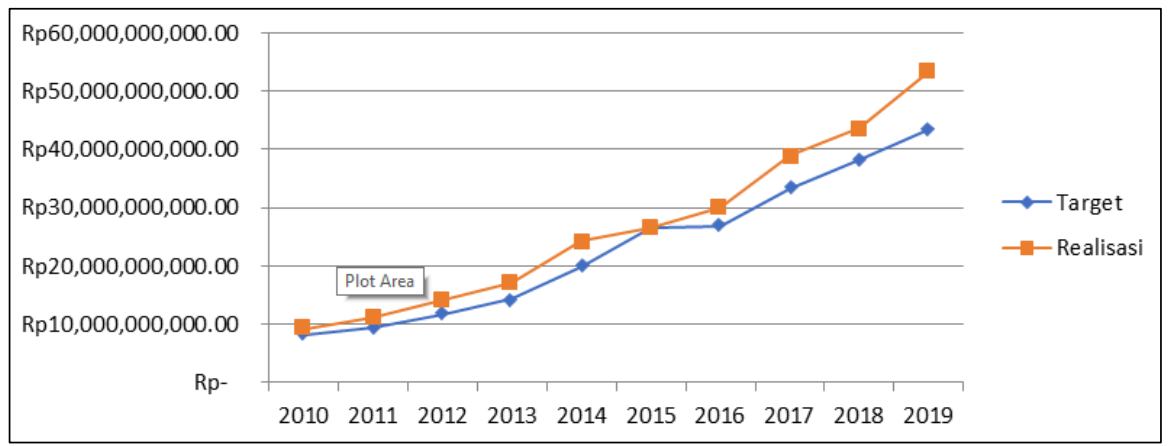

Fig. 4. Effectiveness of PAD from Regional Taxes 2010-2019

Source: Data Processed in 2020

\subsection{PAD from Local Retribution}

The acquisition of PAD from Situbondo Regency has been effective in the last ten years, namely 2010 to 2019 , according to the calculation of the average effectiveness of reaching $92 \%$, meaning it is in the "effective" category. Although the last few years have experienced a volatile growth and decline in earnings. The source of PAD Situbondo from the retribution results showed a decrease in 2011, namely by $11 \%$ with a total revenue of IDR $8,221,138,726.75$, while in 2020 it was IDR 9,246,964,308.00. The acquisition of retribution PAD again increased in 2012 to 2015.

In 2012, an income of IDR 9,137,091,253 was obtained, experiencing a growth of around $11.14 \%$. In 2013, an income of IDR 11,787,252,518.00 was obtained, an increase of about $29 \%$ from the previous year. In 2014 the amount of revenue was Rp. 15,183,322,856.00, an increase of about $28 \%$. The highest increase in income was in 2015 with total retribution receipts of around IDR 21,226,275,086.96 or grew by around $39.7 \%$. Revenues in 2015 were the highest in the past decade. The highest regional levies occurred in 2015, namely around Rp. 21,226,275,086.96 or an increase of around 39.7\% from 2014. However, there are still problems faced including the inadequacy of the revenue target due to changes in the target income from health service levies to others. Legal income and there are mandatory levies that have not made payments because they are still in the legal process. Meanwhile, for 2016 and experienced a significant decline, namely around 7.5 billion (35.5\%) to Rp. $13,682,597,701.00$. Various factors are the cause, including the management of levies for the use of regional assets from land leases for irrigation at the Binamarga and Irrigation Public Works Office which are not optimal. In 2017, the retribution fee decreased again to IDR $9,637,648,123.00$ or decreased by around $29.5 \%$. An increase in revenue of $9.6 \%$ occurred in 2018 with total revenues of IDR 10,563,574,281.00 and in 2019 there was a growth of retribution income of around $10.3 \%$ with a total of IDR 11,656,985,435.00.

Regional levies are levies obtained from health service levies, garbage / cleaning service levies, ID card reimbursement fees and civil registration certificates, parking service levies on public roads, market service levies and motor vehicle testing levies. Currently, the rate of retribution has been adjusted through the Situbondo Regional Regulation concerning Public Service Charges in 2020, where this regional regulation is an adjustment to the Situbondo 
Regency Regional Regulation Number 4 of 2011 concerning Regional Taxes and a new regulation is formed for 2020 to increase the amount of retribution. The following is a graph of the effectiveness of Situbondo Regency PAD revenue which comes from regional retribution from 2010 to 2019.

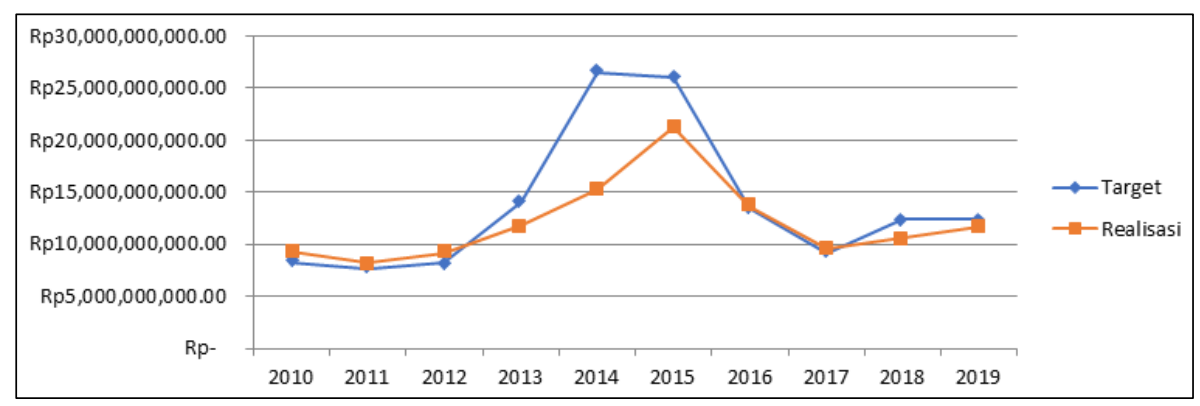

Fig. 5. Effectiveness of PAD from Regional Levies in 2010-2019

Source: Data Processed in 2020

\subsection{PAD from Proceeds from Regional Owned Companies and Management of Separated Regional Assets}

The results of PAD from Regional Owned Companies and Separated Regional Assets Management show a very effective average level of effectiveness, which is around $100.58 \%$ of the plan with the set target, this is because the accuracy of the realization of revenue from the set target shows a fairly good performance even though in several periods the revenue realization target was not met. Significant revenue growth occurred in 2011, namely around Rp. $42.3 \%$ with total revenues of Rp. 5,018,136,616.46, while for 2012 it decreased by $15 \%$ from the previous year with total revenues of around Rp. 4,236,714,534.97. Revenue from PAD from this source increased again although it was not significant in 2013, namely around $1.3 \%$, with the total revenue from this PAD source of IDR 4,292,216,221.02

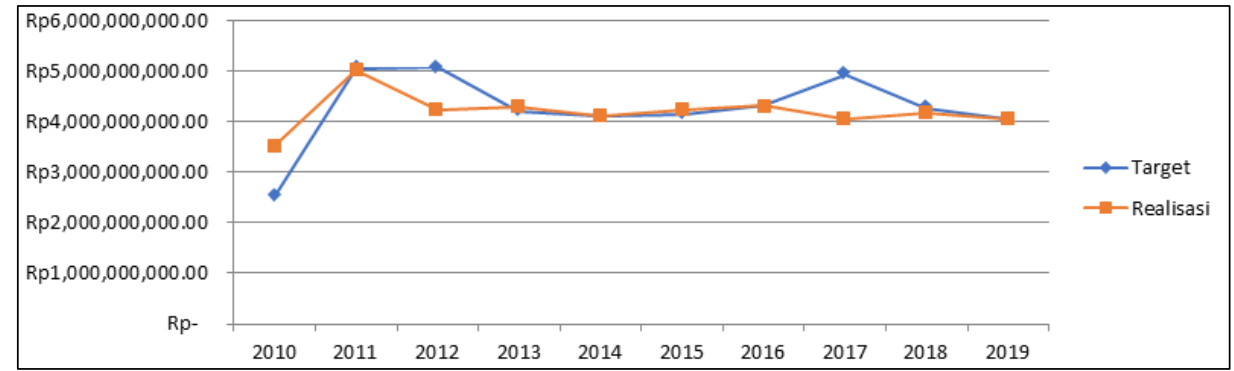

Fig. 6. Effectiveness of PAD from Regional Owned Companies and Management Regional Wealth of 2010-2019

Source: Data Processed in 2020

In 2014, there was a decline in revenue of around $4.6 \%$ with total revenues of $\mathrm{Rp}$. 4,092,920,658.98, Management management in several BUMDs still needs to be improved, so that efforts are made including strengthening BUMD's capital structure through channeling capital assistance obtained through the profit section. for capital participation originating from obtaining dividends from the Regional Development Bank. So that in 2015 there was an 
increase in revenue of around Rp. 4,233,412,108.98, or an increase of about 3.4\% from the previous year. PAD revenue from this source grew again in 2016, namely with the total revenue in that year amounting to IDR 4,316,450,161.00, this number has experienced a growth from 2015 which is around $1.9 \%$. The decline in income from this PAD source occurred in 2017, namely Rp. 4,047,068,403.64 or decreased by around $6.2 \%$ from the previous year. In 2018 , there was an increase of about $3.2 \%$ to IDR $4,177,807,076.24$ and in 2019 it experienced a decrease in revenue from this source, namely $2.9 \%$, with a total revenue of IDR 4,054,829,225.43.

Separated PAD from Regional Owned Companies and Regional Asset Management includes 1) Share of Profits on Equity Participation in Regional Owned Companies / BUMD, 2) Share of Profits on Equity Participation in State Owned Companies / BUMN. The following is the effectiveness of PAD revenue from Regional Owned Companies and the Management of Separated Regional Assets during 2010 to 2019. The following is a graph of the effectiveness of PAD revenue from Situbondo Regency from the results of regional-owned companies and regional wealth management that were separated from 2010 to 2019.

\subsection{Other Legal PAD}

The results obtained from other legitimate PAD experienced a fluctuating growth trend every year, with the second highest average effectiveness level, namely $112.24 \%$ among the four sources of PAD in Situbondo Regency. From 2010 to 2017 there was a significant growth, where in 2010 the income was IDR $25,623,477,612.00$, in 2011 the income was around IDR 36,469,666,770.95. Growth also occurred in 2012, namely the amount of PAD obtained was IDR 36,897,757,993.65. In 2013, an income of Rp. 40,548,549,471.24. In 2014 there was an increase of $112 \%$, that is, an income of Rp. 86,076,956,024.15. In 2015 there was a growth in revenue of $11.9 \%$, namely Rp. 96,379,078,854.80. and 2016 also saw a significant growth of around $30.4 \%$ with total revenues of Rp. 125,756,302,854.80. The highest income originating from other legitimate PAD, namely since the last ten years the high occurred in 2017, with the amount of PAD obtained of Rp. 173,899,575,519.26, where this number experienced a growth of about 38\% from the previous year. The decrease occurred in 2018 about $25 \%$ from the previous year, namely to Rp. $128,891,832,145.69$ while in 2019 the increase in other income was around $5.4 \%$ with the total other income of around $\mathrm{Rp}$. $135,651,888,444.62$.

Other Legal PAD includes 1) The proceeds from the sale of regional assets that are not separated, namely the proceeds from the sale of unused office equipment / supplies, the sale of tree felling, the sale of used building materials, the sale of agricultural products, and the sale of forestry products. 2) Acceptance of Giro Services, namely Regional Cash Demand Deposit Services, Reserve Fund Demand Deposit Services, and Treasury Bank interest income. 3) Receipt of Deposit Interest, namely interest income from Bank Jatim, Bank Mandiri and Bank Rakyat Indonesia. 4) Claims for compensation for regional losses, 5) Fines for late implementation of work include fines in education, health, public works and other fields. 6) Tax penalties include income from hotel tax penalties, restaurant tax penalties, entertainment tax penalties, advertisement tax penalties, groundwater tax penalties, non-metal mineral and stone tax penalties. 7) Retribution fine income includes revenue from public service levies and business service levy fines. 8) Income from returns includes income from returning overpayments of salaries and allowances, income from returning overpayments of official travel, income from returning overpayments of honorariums, income from returning overpayments of transport assistance and income from other repayments. 9) Results of 
revolving fund management. 10) Receipt of PNS Askes Claims 11) Other Income. The following is a graph of the effectiveness of PAD revenue from Situbondo Regency during 2010 to 2019.

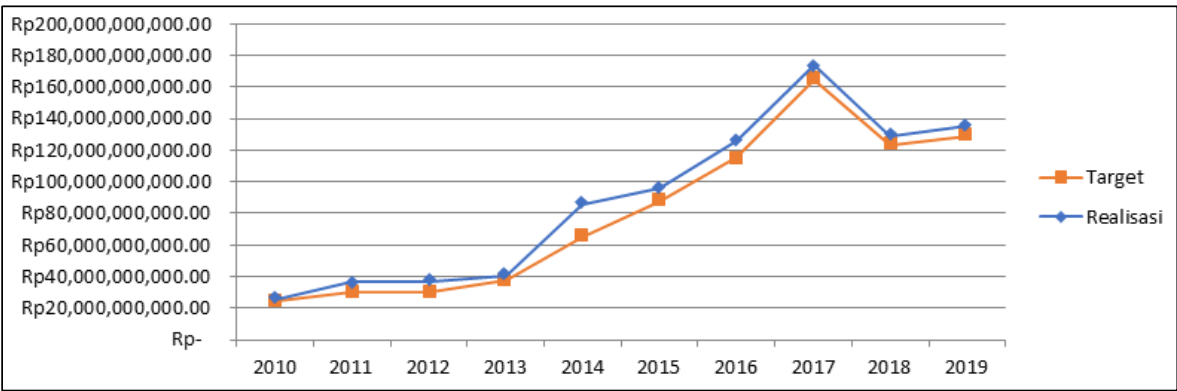

Fig. 7. Effectiveness of PAD from Other PAD that is Legitimate in 2010-2019

Source: Data Processed in 2020

Based on the graph of the four sources of Regional Original Revenue in Situbondo Regency which include Regional Taxes, Regional Retributions, Results of Regional Owned Companies and Management of Separated Regional Assets and Other Legitimate PAD, it still needs to be intensified so that the realization of regional revenues can be according to the target set. So that the efforts that need to be done by the government include:

a) Recording data on taxpayers / levy payers to obtain more accurate data on potential taxes / levies.

b) Implementing more intensive local taxes and levies.

c) Carry out socialization of Regional Tax / Retribution to the community.

d) Minimizing arrears of local taxes / levies.

e) optimizing the monitoring and evaluation of the objects of regional taxes and levies as well as verifying the outstanding receivables.

f) Carry out more transparent and accountable bookkeeping and reporting.

g) Efforts to improve services to the community in the form of providing adequate facilities and infrastructure, improving coordination with the Service / Agencies related to the types of levies according to their authority.

h) Encouraging cooperation between OPDs to implement their Programs and Activities sourced from DAK funds with disbursement stages from the Center so that reports sent are not late and can be transferred by the Center according to the existing stages;

i) Calling for cooperation from SKPD to implement Programs and Activities sourced from DAK funds so that they are in accordance with the reporting stages.

Besides the above policies, the government can also strengthen the role of the community in developing various sources of potential income for the regions. Such as tourism villages, culinary tours, promotional activities / events, cooperation with universities. The progress of the tourism sector has become a new source of income for Situbondo Regency through public and business service fees, the progress of BUMD in the tourism sector can also be a second source of regional income. Strengthening human resource management, supported by living natural resources, is able to increase income from operating profits. 


\section{Conclusion}

The conclusion of the research is that in terms of the Degree of Regional Autonomy of Situbondo Regency, it shows that the contribution of PAD to total Regional Income shows an average of $9.42 \%$ or still below $30 \%$, but the achievement of PAD in Situbondo Regency continues to increase from 2010 to 2019. Contribution each source of PAD to Total PAD in an average proportion shows Regional Taxes of $20.16 \%$, Regional Retribution of $11.38 \%$, Results of Regionally Owned Companies and Management of Separated Regional Assets of $3.83 \%$ Others Legitimate PAD is $64.3 \%$. These results indicate that the majority of revenues come from Other Legitimate PAD. The effectiveness of revenue from PAD sources showed a figure of $100.28 \%$ or "very effective", but for several periods the realization of revenue from PAD showed fluctuations in effectiveness. 2010 (100.97\%), 2011 (101.33\%), 2012 (102.29\%), 2013 (100.94\%), 2014 (101.15\%) and 2018 (101, 43\%) indicates "very effective" criteria, but for 2015 (99.05\%), 2016 (97.18\%), 2017 (98.23\%) and $2019(99.51 \%)$ revenue realization areas are below the target set or fall into the "effective" category.

\section{Acknowledgment}

This research has limitations, including a deeper potential study related to PAD sources that have not been able to be described in detail, given the limited information obtained by secondary data. This research describes the factual data that occurs but not the future income forcasting. Hopefully this limitation can be developed by the next researchers so that the study can be more in-depth.

\section{References}

[1] L. L. D. Berwulo, 'Analisis Pendapatan Asli Daerah (Pad) Di Kota Jayapura', J. Berk. Ilm. Efisiensi., vol. Vol 17, no. No 01, 2017.

[2] A. Halim, Pengelolaan Keuangan Daerah, Edisi Keti. Yogyakarta: UPP AMP YKPN.

[3] M. Kuncoro, Desentralisasi Fiskal di Indonesia dalam Prisma No.4 April 1995. Jakarta: LP3ES., 1995.

[4] M. Kuncoro, Otonomi Daerah, Menuju Era Baru Pembangunan Daerah, Edeisi 3. Jogjakarta : Erlangga, 2014.

[5] R. Sijabat, 'Fiscal Desentralisation and Sustainable Development: Lesson from Local Government Levels in Indonesia. Ontario International Development Agency (OIDA)', Int. J. Sustain. Dev., vol. 9 (3), pp. 39-75., 2016.

[6] M. S. Nasir, 'Analisis Sumber-Sumber Pendapatan Asli Daerah Setelah Satu Dekadeotonomi Daerah', J. Din. Ekon. Pembang., vol. 2, no. 1, pp. 30-45, 2019.

[7] S. Santoso, Statistik Parametik. Jakarta: PT Gramedia Pustaka Umum, 2012.

[8] Julastiana Yaneka dan Wayan Suartana, 'Analisis Efisiensi Dan Efektivitas Penerimaan Pendapatan Asli Daerah Kabupaten Klungkung.’, 2012. 